\title{
THE PROFILE OF DISTAL RADIUS FRACTURE COLLES' TYPE AT DR. SOETOMO HOSPITAL IN 2013
}

\author{
Devina Gabriella Nugroho $^{1^{*}}$, Sulis Bayusentono ${ }^{2}$, Nancy Margaritta Rehatta ${ }^{3}$ \\ ${ }^{1}$ Medical Faculty of Airlangga University \\ ${ }^{2}$ Orthopaedics and Traumatology Department, Medical Faculty of Airlangga University \\ ${ }^{3}$ Anasthesiology and Reanimation Department, Medical Faculty of Airlangga University
}

*Correspondence: Devina Gabriella Nugroho, Faculty of Medicine Airlanga University, Jl. Prof. Moestopo 47, Surabaya. Indonesia.

Email: devina_gabriella@yahoo.com

\begin{abstract}
ABSTRAK
Meningkatnya kasus fraktur akibat perkembangan transportasi dan mobilitas manusia yang pesat saat ini, tidak diimbangi oleh kewaspadaan dalam melakukan aktivitas. Salah satu lokasi fraktur yang paling umum adalah di tangan dan melibatkan bagian distal dari tulang radius, bernama Fraktur Colles. Fraktur Colles adalah fraktur pada bagian pergelangan tangan yang paling umum (hampir $80 \%$ dari patah tulang lengan) dan sering terjadi pada orang tua terutama wanita. Data mengenai distribusi Fraktur Colles belum tersedia. Jika situasi ini terus terjadi, maka akan berdampak pada kurangnya langkah-langkah pencegahan dan metode pemulihan. Desain penelitian ini bersifat deskriptif dan menggunakan data sekunder dari rekam medis di Departemen Orthopedi dan Traumatologi Rumah Sakit Dr Soetomo, Surabaya. Terdapat 37 pasien yang termasuk dalam kriteria inklusi. Fraktur distal radius tipe Colles paling umum terjadi di wanita. Paling sering terjadi pada usia 45-64 tahun. Penyebab paling umum dari fraktur distal radius tipe Colles adalah kecelakaan lalu lintas. Lengan kiri menjadi sisi utama yang paling sering terkena. Kejadian trauma dominan terjadi di jalan. Sering terjadi pada pukul 12.00-18.00. Durasi kejadian hingga masuk ke rumah sakit adalah kurang dari 8 jam.
\end{abstract}

Kata kunci : fraktur distal radius, fraktur Colles'

\begin{abstract}
The fracture cases become increase because the rapid development of transportation and human mobility today is not offset by good vigilance in conducting the activity. One of the most common location is in the hand and involves distal radius part, named Colles' fracture. Colles' fracture is the most common wrist fracture (almost $80 \%$ of the forearm fractures and the incidence rise in elderly people especially woman. The adequate distribution data of Colles' Fracture is not available yet. If this situation keeps going, it will have impacts on the lack of preventive measures and recovery methods. The study was design as descriptive and used secondary data from medical records in Orthopedics and Traumatology Department of Dr. Soetomo Hospital Surabaya. Total 37 patients that included in inclusion criteria. Distal radius fracture Colles' type was common in woman. The most common age was 45-64 years old. Most common causes of fracture was traffic accidents. Left forearm become major affected side. The incidence dominantly occurred at the street. The incidence often occurred at 12.00-18.00. The onset of admission from the incidence place to hospital was less than 8 hours.
\end{abstract}

Keywords : Distal radius fracture, Colles' fracture 


\section{INTRODUCTION}

Fracture of the distal radius is $15 \%$ of the entire incident fractures in adults. Epidemiological survey conducted in Sweden, found $74.5 \%$ of the total number of fractures in forearm is distal radius fracture (Blakeney, 2010).

Colles' fracture is one of the most common type of the distal radius fracture. This type of fracture referred to fracture within $2.5 \mathrm{~cm}$ of the lower end of the radius usually produced by the fall on out elderly people in the world with 18.1 million people or $9.6 \%$ from the total population. The growing number of elderly population especially women in Indonesia will potentialy increasing incidence risk of this kind of fractures. Therefore in this research, I would like to describe about the profile of distal radius fracture Colles' type at Dr. Soetomo Hospital in 2013.

\section{MATERIAL \& METHODS}

This research comprised 37 patients of distal radius Colles' type who were treated at Department of Orthopaedic Surgery of Dr. Soetomo Hospital Surabaya since January 1st, 2013 until December 31st, 2013 and have complete medical records. The characteristic of fractures are stretched hand. It makes the hand will suddenly become stiff, rotated, and then the forearm become pressed (Blakeney, 2010).The mechanism of trauma is unique to each group, with high-energy trauma being more common in the younger group and low-energy trauma being more common in the older group(Nelson, 2012).

According to Kemenkes in 2012, Indonesia is now included in the top five countries with the highest number of extraarticular fracture, dorsal displacement of distal radius bone, dorsal angulation, radial shifting, and radial shortening. The exclusion criteria is patient who does not have complete medical records about distal radius fracture Colles' type. The data that used in this research in the form of secondary data which is collected from the medical of Soetomo hospital Surabaya in 2013. The collected data will be analyzed and processed according selected criteria and present as diagram.

\section{RESULTS}

Distal radius fracture is a very common fracture in forearm, especially Colles' type. It characterized by fracture within $2.5 \mathrm{~cm}$ of the wrist and typically involves 
some dorsal angulation at the site of the fracture. The incidence is high and will interfere the daily activities if it is not be treated seriously. Therefore early diagnosis and proper management is essensial.

According to medical records, distal radius fracture Colles' type patient in Department of Orthopaedic Surgery of Dr. Soetomo Hospital Surabaya on January 1st, 2013 until December 31st, 2013 is 37 patients.

According to the data in 2013, there were 12 male $(32,4 \%)$ and 25 female $(67,6 \%)$ who suffered from distal radius fracture Colles' type. Majority by age 4564 years old with 17 patients $(45,9 \%)$. The most common cause of fracture is traffic accident with 16 cases $(43,2 \%)$. The most frequent affected side in distal radius fracture Colles' type is left forearm with 26 cases $(70,3 \%)$. The right forearm is more rare with 11 cases $(29,7 \%)$. The street become the most common place of incidence mostly happened at 12.00-18.00 with 15 cases $(40,5 \%)$. Twenty-nine patients $(78,4 \%)$ arrived at hospital within or less than 8 hours since the incidence.

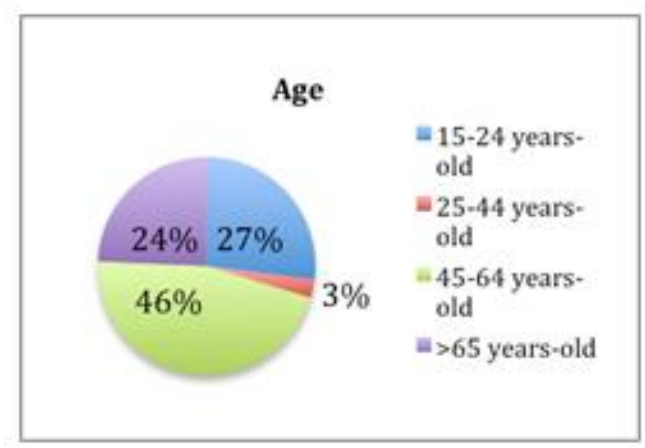

Figure 1. Age distribution of distal radius fracture Colles' type

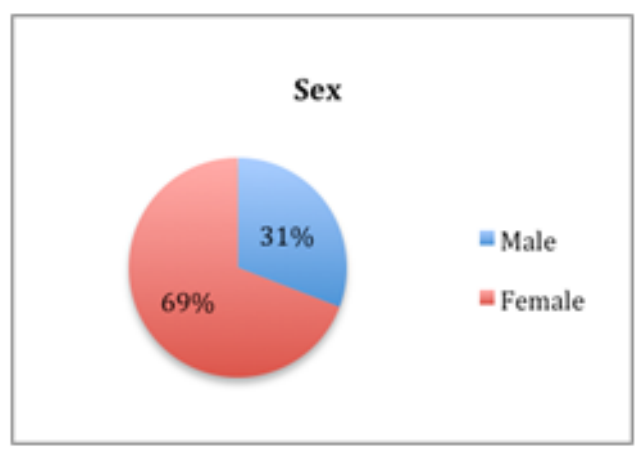

Figure 2. Sex distribution of distal radius fracture Colles' type

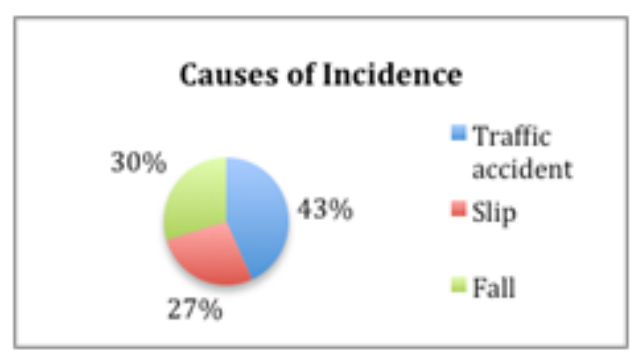

Figure 3. Causes distribution of distal radius fracture Colles' type

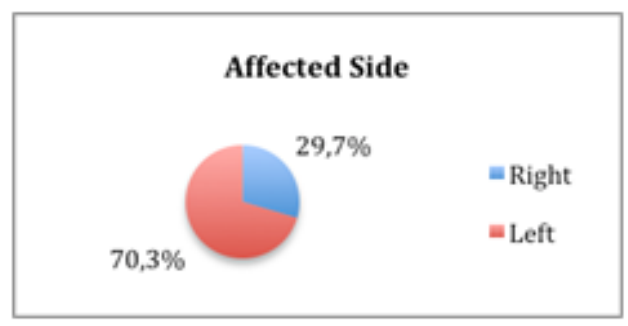

Figure 4. Affected side distribution of distal radius fracture Colles' type 


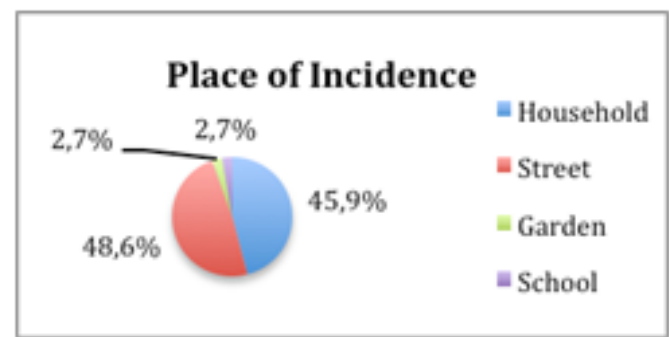

Figure 5. Place of incidence distribution of distal radius fracture Colles' type

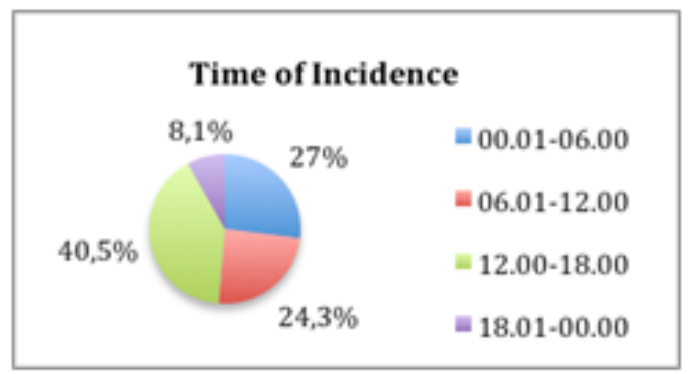

Figure 6. Time of incidence distribution of distal radius fracture Colles' type

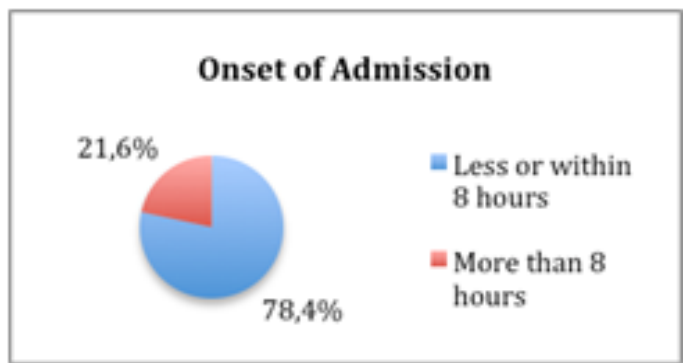

Figure 7. Onset of admission distribution of distal radius fracture Colles' type

\section{DISCUSSION}

Distal radius fracture is a very common fracture in forearm, especially Colles' type. It characterized by fracture within $2.5 \mathrm{~cm}$ of the wrist and typically involves some dorsal angulation at the site of the fracture (Blakeney, 2010). The incidence is high and will interfere the daily activities if it is not be treated seriously. Therefore early diagnosis and proper management is essensial.
Based on figure 1, the most frequent cases of distal radius fracture Colles' type in Department of Orthopedic Surgery of Dr. Soetomo Hospital Surabaya year 2013 happened on age 45-64 years old with 17 cases $(45,9 \%)$. The most common fractures in adult over 40 years old is distal radius fracture Colles' type (Cohen and Abele, 2007). Australia Institute of Health and Welfare in 2011 found rate of 44 per 100,000 population aged 40 years and over suffering from distal radius fracture Colles type. Other finding by Bimoseno \& Heriyanto that the common incidence of distal radius fracture Colles' type were people aged 45-59 years with 80 out of 275 patients in Orthopedic Hospital Surakarta. Productive age is 1564 years old (Tjiptoherijanto, 2011). After age 35-40 all adults begin to lose bone as the breaking down process increases and the building process decreases (National Women's Health Network, 2014). The incidence become increase in that group age because the productivity in that age still high but the bone structure and density become poorer.

Female become the dominant sex type that suffered from distal radius fracture Colles' type with 25 patients (Figure 2). The patients are usually older woman and related to the onset of 
menopausal osteoporosis (Salomon et al, 2010). Although the data fluctuated, the age-standardised rate for this fracture has no downward trend around 70 per 100,000 females and 9 per 100,000 males over the 1998-99 to 2007-08 decade (Australian Institute of Health and Welfare, 2011). Eighty-five percent of women who suffer distal radius fractures have been shown to have low bone mineraldensity and $51 \%$ have osteoporosis (Blakeney, 2010). Osteoporosis are characterized by poor bone strength and are associated with an increased risk of fractures from even slightly traumatic events such as falls from standing height or lower (International Osteoporosis Foundation, 2013).

The figure 3 shows that traffic accident become the most common causes of incidence in distal radius fracture Colles' type with 16 cases $(43,2 \%)$. Munk and Ryan in 2008stated that the fracture can occur caused by motor-vehicle accident with fall on an outstrecthed hand as the machanism of injury. 9 persons in a motor vehicle accident often brace themselves with their hand, bones become broken in the upper extremity as the forces push dorsally on impact with the street (Smith, 2014).

Badan Pusat Statistik in 2012stated that the increasing number of motor- vehicle in Indonesia was 9 million/ year (BPS, 2012). In Surabaya, the ratio of traffic volume and capacity of the road is not too different, such as in Ahmad Yani. The traffic volume was 9507 and road capacity was 10164 . It means that the ratio value was 0,9 which is high compared to normal ratio $(0,75-0,8)$. This condition can be one of factors which increasing the chance of traffic accident (Tahir, 2012).

According to CDC in 2014, the most fractures among older adults were caused by falls and upper arm become one of the common site. Other finding causes in this research are fall with 11 cases (\%) and slip with 10 cases (\%). Most fractures among older adults are caused by falls. Forearm become one of the common fracture site due to falls. The injuries can make patients hard to get around or live independently (CDC, 2014). The incidence of falls can be caused by age associated disease such as Parkinson disease, cognitive decline, and musculoskeletal problems like osteoarthritis, impairment of sensory system, decrease in lean body mass, lumbar spondylosis, and rheumatoid arthritis (Krishnaswamy and Usha, 2003). The incidence can be high when walking on slippery area too, with mechanism of injury: patient either slips or trips, and in attempt to break her fall, lands on her open 
hand with the forearm pronated and makes the wrist become broken (Salter, 1999).

Left side of radius become the most common affected side in distal radius fracture Colles' type with 26 cases (70,3\%). Similar finding from Bimoseno \& Heriyanto in 2011 which stated that the most common side of distal radius fracture Colles' type is the left side with 188 patients $(68.4 \%)$. According to Melton et al in 2010 [20], 66 of the distal radius fractures Colles' type had occurred on the left side and 44 on the right in post menopausal woman. In the control cases (woman without osteoporosis) also had left side as the major affected site with 96 cases out of 105 cases distal radius fracture Colles' type.

About $90 \%$ people are right handed and $10 \%$ are left handed. It means that the people commonly use their right hand in daily activities (McManus, 2009). It had the correlation with the risk of fracture due to cortical bone thickness. Bone have powerful ability to respond to increased muscle loading by changing shape. This adaptive capacity appears to be greatest during growth and is accomplised efficiently in cortical bone by increasing cortical thickness. Greater bone loading frequency result in greater bone formation and greater initial loading stimuli may produce greater gains in bone strength (Marcus et al, 2014). The explanation above indicate that dominant hand will have greater bone strength structure than non-dominant hand because the loading mostly be given to the dominant hand. Poor cortical bone strength play important role in determining distal radius fracture Colles Type (Melton et al, 2014). It is why the incidence of distal radius fracture Colles' type commonly in the nondominant one which is the left side.

The most common place of distal radius fracture Colles' type incidence is street with 18 cases $(48,6 \%)$. Street become dominant place of incident of distal radius fracture Colles' type since the traffic accident become the most common causes in this research. According to NYULMC in 2014, severe trauma such as car accident can increase risk of getting broken wrist. The household also be the second common place of incidence with 17 cases $(45,9 \%)$. The history of distal radius fracture Colles' type could be slip and fall in bathroom usually by elderly woman (Ebnezar, 2010). The minor injuries due to fall from standing position or instability movement which often occurred in daily activities can increase the number of distal radius fracture Colles' type incidence (AAOS, 2013). 
The incidence of distal radius fracture Colles' type occurred mostly at 12.00-18.00 with 15 cases $(40,5 \%)$. That finding is supported by data from Korlantas Polri in 2013 [26] that stated that 5 cases of traffic accident occurred at range of time 12.00-18.00 per day with $32 \%$ from total group of time. Febrianto in 2010also stated that peak of traffic accident at $15.00-19.59(25,48 \%)$. This fact shows that the time at which the highest mobility occurs, at that time incidence of distal radius fractures Colles' type can be more easily obtained too.

Twenty-nine patients $(78,4 \%)$ arrived at hospital within or less than 8 hours since the incidence. This number is good, because if the fracture had been passed the golden period time which is more than 8 hours, the chance of getting infection become higher especially in open fracture (AAOS, 2013). Also early recognition allows for early intervention when complications arise and ultimately provides the patient with the best chance for an optimal outcome (Patel and Paksima, 2010). Infection and improper immobilization would make the healing bone process become poorer. Delayed union or non-union would be formed because the normal calus do not form and replaced by fibrous tissue and cartilages, perpetuating to instability (Kumar et al, 2012). The wrist may be deformed, painfull, stiff, and weak. This condition can interfere with activities of daily living and employment (Duncan and Weiland, 2004).

\section{CONCLUSION}

Retrospective research of distal radius fracture Colles' type at Department of Orthopaedic and Traumatology of Dr. Soetomo Hospital Surabaya since January $1^{\text {st }}, 2013$ until December 31 $1^{\text {st }}, 2013$ had found :

1. The most frequent cases happened on age 45-64 years

2. The common sex type is female

3. The most common causes is traffic accident

4. Left forearm become the most frequent affected side

5. The street become the most common place of incidence

6. Time of incidence mostly happened at $12.00-18.00$

7. Mostly, patients come to hospital within or less than 8 hours. The average onset of admission is 5,5 hours.

\section{SUGGESTION}

The further research about profile of distal radius fracture Colles' type which includes 
amounts of patients and hospitals are needed, thus it can represents the majority of the real incidence in population and the evidence based information about the distribution pattern can be obtained from year to year.

\section{REFERENCES}

AAOS.org (2013) Distal Radius Fractures (Broken Wrist). AAOS. Available from

http://orthoinfo.aaos.org/topic.cfm?to pic $=\mathrm{a} 00412$. Accessed January $23^{\text {rd }}$, 2014

Australian Institute of Health and Welfare (2011) A snapshot of osteoporosis in Australia 2011. Arthritis series no. 15. Cat. no. PHE 137. Canberra: AIHW. Accessed November $3^{\text {rd }}$, 2014

BPS. 2012. Perkembangan Jumlah Kendaraan Bermotor Menurut Jenis tahun 1987-2012. Retrieved November $\quad 2^{\text {nd }}$, 2014 http://bps.go.id/tab_sub/view.p hp?kat=2\&tabel=1\&daftar=1\&id_su byek $=17 \&$ notab $=12 \quad$ Accessed November 3rd, 2014

Bimoseno PA, Heriyanto MJ (2011) Deskripsi Fraktur Radius Distal di Rumah Sakit Ortopedi Surakarta Periode 1 Januari - 31 Desember 2011. Available from http://repository.uii.ac.id/100/SK/I/0/ 00/004/004211/uii-

skripsifraktur\%20radius\%20distal\%2 0fraktur\%20colles $\% 20$ fraktur $\% 20 \mathrm{sm}$ ith-bimoseno-06711183-

6048177565-abstract.pdf. Accessed November $3^{\text {rd }}, 2014$

Blakeney, WG. 2010. Stabilization and Treatment of Colles' Fracture in Elderly Patient. NCBI. Available from http://www.ncbi.nlm.nih.gov/pmc/art icles/PMC3010169/. Accessed January $25^{\text {th }}, 2014$

Blakeney, WG. 2010. Stabilization and Treatment of Colles' Fracture in Elderly Patient. NCBI. Available from

http://www.ncbi.nlm.nih.gov/pmc/art icles/PMC3010169/. Accessed January $25^{\text {th }}, 2014$

CDC (2014) Falls Among Older Adults: Overview. CDC. Available from http://www.cdc.gov/homeandrecreati onalsafety/falls/adultfalls.html. Accessed November $3^{\text {rd }}, 2014$

Cohen HH, Abele JR (2007) Falls Injury of the Extremities. Slips, Trips, Missteps, and Their Consequences. Accessed November $7^{\text {th }}, 2014$

Depkes.go.id. 2012. Sehat dan Aktif di Usia Lanjut. Ministry of Health Republic of Indonesia. Available fromhttp://www.depkes.go.id/index. php? $\mathrm{vw}=2 \& \mathrm{id}=2143 . \quad$ Accessed January $22^{\text {nd }}, 2014$

Duncan SFM, Weiland AJ (2004) Extraarticular Distal Radius Fracture. Hand Surgery $1^{\text {st }}$ Edition. Available from

http://www.msdlatinamerica.com/eb ooks/HandSurgery/sid250917.html. Accessed November $9^{\text {th }}, 2014$

Ebnezar J (2010) Examination of Wrist Joint. Clinical Examination Methods in Orthopedics. Accessed November $4^{\text {th }}, 2014$

Febrianto D (2014) Identifikasi Lokasi Rawan Kecelakaan (Studi Kasus: Jalan Magelang Km 7-Km 16). ETDUGM. Accessed October 30 ${ }^{\text {th }}, 2014$

International Osteoporosis Foundation (2013) Bone Care Fot Postmenopausal Woman. Available from http://share.iofbonehealth.org/WOD/ 2013/thematicreport/WOD13Report.pdf. Accessed 10th November 2014 
Korlantas Polri (2013) Kecelakaan Berdasarkan Waktu. Available from http://www.korlantas-irsms.info/. Accessed October 30 $30^{\text {th }}, 2014$,

Krishnaswamy B, Usha G. (2003). Falls in older people. Madras Medical College. Chennai. Accessed November $8^{\text {th }}, 2014$

Kumar V, Abbas AK, Aster JC. (2012) Fracture. Robbins Basic Pathology. Accessed November $1^{\text {st }}, 2014$

Marcus R, Feldman D, Dempster D W, Luckey M, Cauley JA (2013) General Patophysiology of Osteoporosis. Osteoporosis Fourth Edition. Accessed October $28^{\text {th }}, 2014$ McManus, IC (2009) The History and Geography of Human Handedness. Language lateralisation and psychosis, 37-58. Accessed October $30^{\text {th }}, 2014$

Melton JL, Christen D, Riggs BL, Achenbach SJ, Muller R, Lenthe GHV, Amin S, Atkinson EJ, Khosla S (2010) Assessing Forearm Fracture Risk in Postmenopausal Women. Osteoporos Int; 21(7):1161-1169. Accessed October $29^{\text {th }}, 2014$

Munk PL, Munk P, Ryan A (2007) Teaching Atlas of Musculoskeletal Imaging. Thieme Medical Pub. ISBN:1588903729. Accessed February $5^{\text {th }}, 2014$,

National Women's Health Network (2014) Osteoporosis. NWHN. Available from https://nwhn.org/osteoporosis. Accessed November $3^{\text {rd }}, 2014$

Nelson, DL (2012) Distal Fractures of the Radius. Medscape. Available from http://emedicine.medscape.com/articl e/1245884-overview\#a0101. Accessed January $24^{\text {th }}, 2014$

NYULMC (2014) Colles' Fracture. NYULMC Musculoskeletal Rehabilitation Network. Available from http://nyulmcrehab.med.nyu.edu/conditions-we- treat/conditions/colles-fracture. Accessed November $4^{\text {th }}, 2014$

Patel V P, Paksima N (2010) Complication of Distal Radius Fixation. Bulletin of the NYU Hospital for Joint Diseases 2010;68(2):112-8 Accessed October $17^{\text {th }}, 2014$

Salomon L, Warwick D, Nayagam S (2010) The Wrist and Hand. Apley's System of Orthopaedics and Fractures. Accessed November $6^{\text {th }}$, 2014.

Salter BR (1999) The Wrist and Forearm.Textbook of Disorders and Injuries of the Musculoskeletal System: An Introduction to Orthopaedics, Fractures, and Joint Injuries, Rheumatology, Metabolic Bone Disease, and Rehabilitation. William \& Wilkins. Accessed November $1^{\text {st }}, 2014$

Smith E (2014) Extremity Trauma. Autoaccident.com. Available from http://www.autoaccident.com/extrem ity-trauma.html. Accessed November $1^{\text {st }}, 2014$

Tahir, A (2012) Angkutan Massal Sebagai Alternatif Mengatasi Persoalan Kemacetan Lalu-lintas Kota Surabaya. SMARTek, 3(3) Accessed November $8^{\text {th }}, 2014$

Tjiptoherijanto, P (2001) Proyeksi penduduk, angkatan kerja, tenaga kerja, dan peran serikat pekerja dalam peningkatan kesejahteraan. Majalah Perencanaan Pembangunan. Accesed October $22^{\text {nd }}, 2014$ 